\title{
МОВНІ КЛІШЕ В МАС-МЕДІЙНІЙ КОМУНІКАЦІЇ: ОСОБЛИВОСТІ МАНІПУЛЯТИВНОГО ВПЛИВУ
}

Шарманова Н. М. Мовні кліше в мас-медійній комунікації: особливості маніпулятивного впливу.

У статті проаналізовано питання маніпуляції масовою свідомістю за допомогою стандартизованих стереотипних одиниць 3 мови новітніх українських медіа. Масовий мовний вплив на реципієнта осмислюється 3 погляду лінгвопрагматики. Використання мовних кліше визначає маніпулятивні впливи на колективну свідомість.

(ㄱ Н. М. Шарманова, 2015. 
Ключові слова: мас-медійний дискурс, мовне кліше, прагматика, маніпуляція, маніпулятивний вплив.

Шарманова Н. Н. Языковые клише в масс-медийной коммуникации: особенности манипулятивного воздействия.

В статье рассматриваются вопросы манипуляции массовым сознанием в аспекте использования стандартизированных стереотипных единиц в языке современных украинских медиа. Массовое воздействие на реципиента раскрывается с позиции лингвопрагматики. Использование речевых клише определяет манипулятивное воздействие на коллективное сознание.

Ключевые слова: масс-медийный дискурс, языковое клише, прагматика, манипуляция, манипулятивное воздействие.

Sharmanova N. M. Peculiarities of language cliches manipulative influence on massmedia communication.

The article reveals the problem of consciousness manipulation process and the role of stereotype language units in it. Language influence made upon the addressee is considered in the aspect of linguapragmatics. The research also shows pragmatics of language cliches in modern Ukrainian media. Using clishes determines the opportunity to manipulate both collective consciousness.

Key words: massmedia discourse, language cliché, pragmatic, manipulation, manipulation influence.

Вплив на масову свідомість у комунікаційному просторі визнають одним із значних технологічних досягнень сучасності (Г. Г. Почепцов), а царину мас-медіа неможливо уявити, на думку лінгвістів, без планування мовного впливу й контролю за його ефективністю [5]. Ужиток маніпулятивних стратегій і тактик впливу в медіакомунікації тісно пов'язаний з особливостями самої медіасфери, до якої входять преса, телебачення, радіомовлення, Інтернет і яка детермінує «живий зворотний зв'язок адресантів і адресатів, учасників соціальної комунікації, вона стає надійним джерелом для вивчення динаміки мовних змін, активних процесів у мові й мовній свідомості наших сучасників» [3, с. 123]. А між мовною свідомістю сучасного українця і розгалуженим інформаційним простором ЗМК, як акцентує С. Я. Срмоленко, існують причинно-наслідкові зв'язки [3, с. 124]. Це видається доцільним в осмисленні питань щодо маніпуляцій масовою свідомістю за допомогою мовних кліше, адже в сучасному мовознавстві залишаються нерозв'язаними питання комплексного опису механізмів масової комунікації, пов'язаних із актуалізацією автономних лінгвістичних утворень. Мовні кліше, транслюючи 
процеси стандартизації мови загалом, відображають у свідомості часто повторювані явища дійсності.

Під мовними кліше розуміємо стереотипні комбінації словесних знаків, регулярні автономні блоки із традиційно усталеними значенням і формою: Світ съогодні («События дня», канал «Україна», 07.02.2014; 25.02.2014; 28.05.201405.06.2014; 23.12.2014; 23.04.2015; $\mathrm{TCH}$, канал «1+1», 23.03.2014; 27.05.2014); 3) «Новини дня», канал IHTEP, 14.11.2014); Схід сьогодні («События дня», «Україна», 02.06.2014; 04.06.2014; 11.06.2014); Донбас сьогодні («События дня», «Україна», 25.02.2015) тощо.

Мета розвідки полягає в розкритті маніпулятивного впливу кліше в українському мас-медійному просторі. Мета передбачає висвітлення таких завдань: 1) з'ясувати феномен мовної маніпуляції у світлі інтегральних властивостей сучасної медіакомунікації; 2) визначити маніпулятивні можливості мовних кліше в новітньому медіадискурсі.

Залучення масової аудиторії до спілкування в різних типах засобів масової комунікації передбачає ті чи ті дискурсивні й комунікативно-прагматичні вектори у функціонуванні сучасної української мови. С. П. Бибик зауважує: «Коли ми говоримо про вплив засобів масової інформації на мовну свідомість читачів чи слухачів, то повинні враховувати специфіку нинішніх 3МІ» [2, с. 133]. Дослідниця стверджує: у контексті питання про вплив мови ЗМК на мовну свідомість українців варто акцентувати на тому, що піддається змінам не тільки сам літературний стандарт сучасної української мови - усні й писемні мовні норми, - руйнується перш за все стильова норма, сформована за попередній період історії мови - до 90-х років XX ст.: «На зміну врівноваженому стилю подачі інформації прийшла мода на перенесення на шпальти висловлення інтерв'юера, яке передає афективні стани мовців, їх розкутості, характерної для побутової ситуації, їх епатажності» [2, с. 134].

Дискурсивний характер мови сучасної медіакомунікації визначають функціональна спрямованість ЗМІ, соціально-політичні умови (демократизація суспільства), зміщення в бік діалогічності, накладання постмодерністської техніки письма (I. В. Шумкіна). Крім того, дослідники новітніх медіа (С. П. Бибик, Ц. Йотов, I. Л. Михайлин, О.Г. Руда та ін.) визнають дискурсивність журналістських текстів 3 орієнтацією на сьогодення й повсякденну (ㄱ Н. М. Шарманова, 2015. 
мовну практику, універсальність лексико-тематичного різноманіття, мовні інновації, діалогічність у поєднанні 3 інтертекстуальністю, дифузію елементів усності як складової аргументативних тактик, документальність і фактуальність специфічними ознаками сучасної медіакомунікації [2, с. 134].

Зауважимо, що неабияка увага масової аудиторії до медіадискурсу пов'язана 3 його винятковою значущістю для життєдіяльності сучасного суспільства: у текстах ЗМІ знаходять відображення важливі для соціуму культурні й політичні події, а мова засобів масової комунікації постає репрезентантом і суспільно престижним різновидом національної мови - «як мова, що своїми значеннями об'єднує націю» (Г. Я. Солганик). Стосовно значущості мови медіапростору в загальнонаціональному вимірі, то, на наш погляд, авторитетною є думка С. Я. Срмоленко: мова новітньої масової комунікації - це «не лише пасивний об'єкт наукових розвідок - лінгвістичних і журналістських, соціологічних, а й активний суб' єкт, який забезпечує важливу суспільну функцію української мови реалізацію ї літературного стандарту, тобто нормованої, 3 культуромовними традиціями загальноприйнятої мови спілкування» [3, c. 123].

Властива публіцистичним текстам «спрямованість на вплив i переконання визначає особливі взаємостосунки між сторонами спілкування... Це не констатувальне, а імперативне мовлення, воно покликане не лише повідомити про що-небудь..., але й навіяти це ставлення адресату, тобто зрештою це мовлення, покликане вплинути на переконання або поведінку читача, на його оцінку тих чи тих факторів» [11, с. 64]. Ураховуючи залежність оцінки інформації реципієнтом від іiі розміщення в тексті, адресант «акцентує факти та події, що є значущими, на його думку, та нівелює менш необхідну інформацію» задля досягнення загальної комунікативної мети [1, с. 43].

Наголошуючи на зростанні ролі ЗМК у процесах формування масової свідомості, автори колективної монографії «Реклама та PR у масовоінформаційному просторі» зазначають, що на сьогодні практично не підлягає сумнівам сугестогенна домінанта сучасних медіа. Спираючись на результати лінгвістичних, психологічних i соціологічних досліджень, вони акцентують, що такі підходи «сприяють з'ясуванню природи сугестивних імплікованих субстратів, 
проте їх безпосередня експлікація відбувається насамперед на рівні лінгвістичних конекторів, які і здійснюють відповідну впливову експансію, що увиразнює необхідність їх якнайдетальнішого аналізу і 3 огляду на важливість дослідження феномену сугестії загалом, i 3 огляду на роль ЗМІ у формуванні суспільної думки, що, своєю чергою, передбачає коректне прогнозоване використання відповідних лінгвістичних маркерів» [9, с. 234].

Маніпулятивний вплив є об'єктом лінгвістичних, психологічних, філософських, соціологічних і політологічних досліджень (Л. Р. Безугла, Б. Бессонов, Р. М. Блакар, Д. Болінджер, Х. Вайнріх, Є. Л. Доценко, О. В. Зарецький, В. В. Зірка, О. С. Іссерс, С. Г. КараМурза, В. Клемперер, Т. Ю. Ковалевська, Н. В. Кондратенко, Г. А. Копніна, Ф. Менц, О. Г. Руда, І. О. Романченко, Б. Я. Шарифуллін, І. Ю. Шкіцька, Е. Шостром та ін.).

Спираючись на вироблені в різних царинах погляди щодо сутності маніпуляції, Г. А. Копніна подає таке узагальнення: «Мовленнсва (мовна) маніпуляція (маніпулювання) - різновид маніпулятивного впливу, здійснюваного шляхом умілого використання певних ресурсів мови задля прихованого впливу на когнітивну й поведінкову діяльність адресата» [6, с. 25].

Феномен маніпуляції полягає в узагальненні різних стратегій, тактик і прийомів. Сам термін має досить високий ступінь диференціації та виступає родовим щодо цілої системи понять. О. Г. Руда, зважаючи на думку попередників (Г. Грачов, І. Мельник), наголошує: «До цієї системи входять: маніпулятивний вплив, маніпулювання (в політиці, суспільною свідомістю), міжособистісні маніпуляції, соціальнополітичні маніпуляції особистістю тощо» [10, с. 52].

Маніпуляцію дослідники визначають як складову технології влади (С. Г. Кара-Мурза). Тому маніпуляції свідомістю визначені соціальною дистанцією між елітою й широкими масами i тим соціальним напруженням, яке породжує величина цієї дистанції (Я. В. Любивий). Стандартний набір інструментів владного впливу становлять сила, примус, стимулювання, переконування й маніпуляції. Інформаційний вплив на суспільство здійснюється якраз за допомогою двох останніх. Осмислюючи маніпулятивні стратегії й тактики в сучасному українському політичному дискурсі, трансльовані через 3МI, О. Г. Руда акцентує на специфіці цих () Н. М. Шарманова, 2015. 
інформаційних інструментів впливу: «Проте якщо метою переконування $\epsilon$ перетворення людей на однодумців, розкриття ідей i планів, побудова комунікації, то маніпуляція передбачає якраз примус, але не фізичний, а психічний. Маніпулятор не переконує, а констатує, що переконання, ідеї й плани в нього такі самі, як і в об'єктів впливу. Від переконування маніпуляцію відрізняє масований вплив, навала сигналів (так званих 'меседжів') суспільству через різноманітні канали» [10, с. 52-53].

Маніпуляція становить спосіб зміни чи коригування картини світу реципієнта, що реалізується за допомогою вербальних складових, що визначаються низкою мовних засобів, які взаємодоповнюються i взаємоперетинаються, супроводжуються невербальними компонентами (наприклад, у теле- та інтернетпросторі). Адже результат маніпулятивного впливу завершеного фрагменту мас-медійного повідомлення залежить від сумарного впливу симбіозу всіх наявних елементів, і зокрема від ефективності маніпулятивної дії мовних і позамовних компонентів.

Маніпулятивний вплив на масового адресата в засобах масової інформації мають свої особливості в аспекті способу передачі інформації (опосередкованість мас-медіа і неможливість миттєвого коригування засобів впливу залежно від реакції адресата) і сутності адресата інформації (масовий / потенційний індивідуально-масовий адресат). На відміну від специфіки міжособистісного спілкування, маніпуляція в мас-медіа не передбачає врахування індивідуальних властивостей реципієнта, a, отже, може йтися і про конкретного, i про можливого адресата та більш універсальні мовні засоби, розраховані на різнорівневу аудиторію. Це дає змогу розглядати «спілкування за допомогою засобів масової комунікації <..> як соціальну взаємодію»[12, с. 54].

Дослідники механізмів маніпуляції розглядають ії як складне багаторівневе, багатокомпонентне явище, де маніпулятивний вплив грунтується на принципах прихованості, майстерності, існування або створення ілюзорної дійсності: «Досягти результату за допомогою мовної маніпуляції можна лише за умови некритичного сприйняття поданої інформації адресатом, однак вона має подаватися приховано, у вигляді імплікатур» [9, с. 277]. У цьому і виявляються інтегральні ознаки мас-медійного дискурсу, семіотика якого грунтована тим, що 
«масова інформація характеризується систематичним застосуванням поряд зі словом цілої низки знакових систем, які відіграють важливу роль в організації іiі тексту. У змістовому плані твори масової інформації загалом похідні від інших, передусім прозових, видів слова. У плані отримання i сприйняття масова інформація характеризується визначеністю аудиторії й ефективністю. Ефективність масової інформації виявляється в тому, що іiі зміст регулярно відтворюється в мовленні найбільш широких верств населення» [12, с. 39].

На вживанні стереотипних, готових мовних форм вираження неодноразово акцентували Ch. Bally, S. Leszczak, E. Partridge, R. Rathmayr, J. Rogers, В. В. Виноградов, Т. Г. Винокур, В. К. Гак, I. Р. Гальперін, В. В. Гвоздєв, Т. М. Дрідзе, Г. А. Копніна, В. В. Красних, М. А. Кронгауз, О. С. Кубрякова, Л. Маккензен, Л. І. Мацько, Р. К. Міньяр-Бєлоручев, Т. М. Ніколаєва, Б. Ю. Норман, Д. Е. Розенталь, О. Б. Сиротиніна, Н. М. Сологуб, Л. В. Щерба, Р. О. Якобсон та ін. Дослідженню ролі кліше у процесі сприймання й оцінки медійної інформації присвячені праці Ю. О. Александровського, О. Р. Лурії, І. І. Ляхова, Е. М. Соколова та ін. Доведено, що семантичні і прагматичні ознаки публіцистичних текстів відбивають стереотипні очікування масової аудиторії та політико-економічні вподобання власників видань $[4$, с. 4]. Серед таких засобів використовується один iз різновидів кліше - ідеологічні кліше, маніпулятивний потенціал яких у контексті стереотипізації подано в роботах Г. А. Копніної, Г. Г. Почепцова, О. П. Сковороднікова, О. К. Шевченка та ін.

Сфера застосування конструкцій і фіксоване місце в контексті, стереотипність, конвенційність, ритуальність ужитку в мас-медіа, нейтральність вираження, прирощування стилістичного ефекту в різних дискурсивних ситуаціях визначають прагматику мовних кліше. Основною сферою функціонування кліше у ЗМК є їх інформативне, волюнтативне, сугестивне застосування. Л. В. Завгородня наголошує: «Система стереотипів дає змогу реагувати на різні, часом суперечливі життєві ситуації і діяти відповідно до реалій існуючого суспільства» [4, с. 11]. Мовні кліше як економні комунікативні утворення здатні лаконічно реалізувати певні стратегії і тактики в масовій комунікації. Виконуючи регулятивну функцію, мовні кліше реалізують комунікативно-прагматичні завдання, спрямовані на якісну

(ㄱ Н. М. Шарманова, 2015. 
організацію мас-медійного дискурсу та забезпечення окреслених для нього стратегій.

Своєрідністю мовних кліше у мові мас-медіа як характерних одиниць комунікації, $€$ забезпечення ними чітких комунікативнопрагматичних впливів. Як і інші дискурсивні практики, сучасний медіадискурс актуалізує мовні засоби, здатні маніпулювати масовою свідомістю. Услід за I. В. Решетаровою, Л. Р. Безугла й I. О. Романченко в монографії «Лінгвопрагматика дискримінації у публіцистичному дискурсі» зазначають: «ЗМІ $є$ основним інструментом поширення повідомлень, які впливають на громадську свідомість» [1, с. 44].

Аналіз сучасних засобів масової інформації, здійснений дослідниками процесів і механізмів маніпуляції, показав існування чотирьох основних вербальних складових маніпулятивного впливу застосування комічного, нагнітання страху, використання числа, відображення чуток. Так, Г. М. Подшивайлова виділяє 4 мовні засоби маніпулятивного впливу в політичному дискурсі, як номінування, взаємодія мовних кліше й експресивів, метафоричність мас-медійних повідомлень, імпліцитна інформація, використання іншомовних вкраплень як вияв дво-/ тримовності можливого реципієнта [8].

Кліше як повторюваний у схожих ситуаціях мовний знак дозволяє втілювати суспільні орієнтири на рівні ідеологічних смислів, актуальних у певний момент і поширюваних в українському соціумі. Маркування за допомогою кліше суспільно значущої інформації на сьогодні визначає діяльність вітчизняних медіа - національних і комерційних, традиційних та мережних. Порівняємо найбільш уживані нині кліше в мові мас-медіа: гуманітарний рейс; гуманітарний конвой (так званий гуманітарний конвой / конвой Путіна); гуманітарний коридор; гуманітарний колапс, гуманітарна допомога; гуманітарна підтримка; гуманітарний штаб. Мовні кліше як суспільно-політичні номени описують події українського сьогодення і викликають чи не найбільший інтерес у масового адресата, і не тільки в Україні, а й світі.

Актуалізація кліше запобігає або сприяє вияву мовної агресії, що перш за все залежить від контексту подання інформації, зумовленого системою соціальних та ідеологічних стереотипів, які у сфері масової комунікації відбиваються не лише крізь зміст тексту, але й через план 
його вираження (мовну і формальну структуру), як-от: мирний процес; мирне врегулювання конфлікту; ядерний конфлікт; волонтерський рух; волонтерський штаб; волонтерська допомога (допомога волонтерів). Надмірна політизація й поляризація суспільства, обгрунтовано підвищена увага до низки проблем соціальної сфери передбачають широкий маніпулятивний резонанс 3 боку масової аудиторії. Особливо виразно це відстежується на рівні серійної сполучуваності в двокомпонентних структурах ад'єктивносубстантивного й субстантивно-субстантивного типу, які домінують той чи той фактологічний концентр. Наприклад: 1) колапс (гуманітарний колапс; економічний колапс; екологічний колапс; повний колапс /вдасться уникнути повного коллапсу/; справжній колапс; колапс долара); 2) загроза (світова загроза; терористична загроза; загроза захоплення влади / території); 3) територія (територія, підконтрольна / непідконтрольна Україні / Києву, украӥнській владі, українським військовим, силовикам/; територія, підконтрольна / непідконтрольна ДНР / ЛНР, сепаратистам, террористам, проросійським бойовикам/) тощо.

Сугестивність мас-медійних повідомлень визначається також використанням лексики 3 позитивною семантикою у ролі смислових концентрів мовних кліше. Наприклад, доля: Доля України; Доля Донбасу (ТCH, канал «1+1», 05.02.2015); Доля Дебальцевого («События дня», канал «Україна», 17.02.2015); Доля Надії (ТСН, канал «1+1», 18.02.2015; 23.03.2015); життя: Окуповане життя (ТСН, канал «1+1», 02.06.2013); Солдатське життя («Новини», канал «2+2», 11.11.2014); Життя триває (ТСН, канал «1+1», 19.09.2008); Життя - ие вибір. Життя в Україні практично завжди вибори («Подробиці тижня», канал IНТЕР, 14.09.2008); Життя як воно $\epsilon$ («Час новин», 5-й канал, 24.10.2008); гідність: Революиія гідності; Промінь гідності /запалити Промінь гідності/ («События дня», канал «Україна», 20.02.2015); Мари гідності («События дня», канал «Україна», 22.02.2015); Хода гідності («Новини», 1-й Національний канал, 22.02.2015). Такі лексеми дослідники називають актуалізаторами семантичного маніпулювання, акцентуючи на тому, що лексеми 3 позитивною семантикою «викликають у реципієнтів відповідні емоції, що є сприятливими умовами для навіювання (інколи цей прийом називають 'магія слів')» [9, с. 269]. Сугестивні впливи за (ㄱ Н. М. Шарманова, 2015. 
допомогою цього маніпулятивного прийому (актуалізація в мовних кліше слів із позитивним навантаженням) зумовлені тим, що створюється позитивний модус в асоціативному ланцюжку при сприйнятті суспільно значущої інформації.

Лексика загально описового характеру, що відображає інтерпретацію в сучасних медіатекстах наскрізної суспільної тематики, становить основний фонд лексикону інформаційноаналітичних програм [12, с. 46-47]. Оскільки сучасні ЗМК актуалізують тематику оновлення українського суспільства, то це знайшло, відповідно, своє відображення в стереотипних одиницях із компонентом новий: Нове життя (ТСН, канал «1+1», 09.03.2013); Новий сезон (реклама шоу «Ревізор» на каналі СТБ, 26.02.14); Нові правила (реклама шоу «Україна має талант. Шостий сезон» на СТБ, 26.02.14; у назві сюжету («Вікна», канал СТБ, 29.04.2015); Новий кабмін («Вікна», канал СТБ, 26.02.2014); Нові міністри. («Вікна», канал СТБ, 05.02.2013); Новий уряд. Старі проблеми («Вікна», канал СТБ, 27.02.2014); Нові протести («Час новин», 5-й канал, 29.08.2014); Нова конституція («Час новин», 5-й канал, 11.04.2014) тощо. Сугестивний потенціал ужитку слова новий (нова, нове, нові) має на меті апелювання до емоціогенних зон свідомості, а в поєднанні із суспільно-політичною лексикою відбувається «утворення сенсовіритмомелодійної континуальності мовлення, спричиняє 'утилізацію свідомості’ і відкриває доступ до підсвідомих ресурсів» [9, с. 237].

Низка суспільно-політичних і соціальних факторів актуалізували нині ужиток лексики, що відтворює військово-політичну ситуацію на Сході України. Порівняємо: якщо в 2009 році у телепросторі стосовно української військової галузі гасловим сприймалося кліше Солдат спочиває - служба триває («Вікна», канал СТБ, 26.05.2009), то навесні 2014 р. поширеним стало гасло Армія з народом (із реклами «565» на підтримку Української армії березень - квітень 2014), влітку 2014 року у зв'язку з трагічними подіями під Іловайськом - Героям слава (липень 2014) і т. п. Нині в ужитку актуалізувалися кліше на зразок На лінї фронту («События дня», канал «Україна», 24.02.2015); Військова атака (ТСН, канал «1+1», 11.02.2015); Прощзвай, зброє! («События дня», канал «Україна», 23.02.2015; 24.02.2015). Військова тематика наскрізно пронизує інформаційні повідомлення та аналітичні програми у вітчизняних медіа, що детермінує функціонування низки 
мовних одиниць у заголовках, як-от: Повернення героїв (ТСН, канал «1+1», 23.02.2015); Діти війни («События дня», канал «Україна», 05.06.2014); Жертви війни («Час новин», 5-й канал, 06.02.2015); День війни («События дня», канал «Україна», 10.02.2015); День на фронті («События дня», канал «Україна», 23.03.2015); Військова зрада (ТСН, канал «1+1», 04.02.2015); воєнний трофей (ТСН, канал «1+1», 23.02.2015); Воєнні будні (канал «2+2», 29.08.2014).

У новітньому мас-медійному дискурсі виразно відстежується механізми нагнітання страху. Виділяють певні види масового страху: 1) побоювання іноземного впливу (різноманітних видів залежності України від інших держав, а також страх розколу країни); 2) страх перед сепаратизмом (неофашизмом, сталінізмом, а в опозиційних друкованих 3МІ - націоналізмом), 3) страх тероризму, 4) страх перед бандитизмом (кримінальними структурами), 5) містичний страх (метафоричне звернення до страху перед надприродними силами / істотами), 6) переживання за безпосереднє оточення адресата [8, с. 13-14].

Проілюструємо зазначені вияви побоювань з позиції зовнішнього реагування на ті суспільні події, що відбуваються в Україні, низкою мовних кліше, що активно функціонують в сучасних медіатекстах: Російська загроза (ТСН, канал «1+1», 09.03.2013); Майбутня агресія (1-й Національний канал, 05.02.2015); Реакція свіmy (ТСН, канал «1+1», 25.02.2014; «События дня», канал «Україна», 25.02.2014); Світова реакція («Час новин», 5-й канал, 14.06.2014); Реакuія згори («События дня», канал «Україна», 27.02.2014); Міжнародна реакція («Вікна. Новини. Спецвипуск», канал СТБ, 27.02.2014); (ТСН, канал $« 1+1 », 18.02 .2015)$ і т. п.

Вияв мовної агресії детермінує появу мовних одиниць із семантикою захисту (захист, оборона, укріплення). Так, 3 позиції зовнішньополітичного реагування й підтримки світової спільноти для України внутрішні суспільні події сприймаються за допомогою маркера оборона: Колективна оборона (ТCH, канал «1+1», 05.02.2015). Порівняємо: оборона Маріуполя / Донецького аеропорту / Дебальиевого / Пісків; тримати оборону тощо.

У мас-медіа виразними є спроби нівелювати потенціал впливу страхів. Крім того, відстежується вияв нейтралізації можливої недовіри реципієнта, попередження неправильного розуміння ним висловленого. Відтак маємо стандартизовані фрагменти в писемних й 
усних публіцистичних текстах полемічного характеру: Можливо, ви не повірите, але хай ие переконає...; Може видатися, щзо...; Не варто розуміти це.... і т. п. [8]. Відображення чуток пов'язане з поняттям сенсаційності. Задля створення ілюзії достовірності посилаються на деякі «джерела» без уточнення, на які саме, наприклад: експерти зазначають; на думку експертів і т. п. Задля спростування чуток адресант апелює до думки реципієнта як учасника можливої фактологічної події. Такий маніпулятивний прийом аргументації в межах психологічного впливу на реципієнта - аргумент до авторитету - номінують «аргументом до несміливості», який за вмілого застосування може використовуватись як потужний інструмент впливу на масову свідомість [9, с. 231].

Окремим засобом маніпулятивного впливу розглядаємо метафоризацію фактологічної ситуації в мас-медіа, що представлено такими прикладами: Політичні ігри (ТСН, канал «1+1», 28.01.2013); Великі політичні ігри («Час новин», 5-й канал, 06.02.2015); Дипломатичний фронт («События дня», канал «Україна», 24.02.2015); Газовий фронт; енергетичний фронт («События дня», канал «Україна», 24.02.2015); Зірковий фронт /баталії на зірковому фронті/ («События дня», канал «Україна», 24.02.2015); Іловайський котел («Вікна», СТБ, 07.09.2014); Дебальиівський котел / плацдарм; Дебальиівська дуга / коло («События дня», «Україна», 30.01.2015; 25.02.2014; перезавантаження влади («События дня», «Україна», 25.02.2014); переформатування влади («События дня», «Україна», 25.02.2014; 1-й Національний канал, 06.03.2014); відкрита війна; щзаблі влади («ШО», 25.03.13); чиновнищьке іго («Українська правда»; http://pravda.com.ua, 19.11.2013). Метафора грунтується на імпліцитному порівнянні предметів, об'єктів, явищ у процесі асоціативно-образного сприймання дійсності, тому в мовній стереотипізації суспільних явищ метафору слід розглядати як експресив $[8$, с. 10]. Отже, аргументним при цьому є погляд Л. О. Кудрявцевої: «Ефективний вплив на читача/ слухача ЗМІ передбачає обов'язкову апеляцію до його емоцій, оскільки вони завжди ‘ближче' до сприйняття світу людиною... йдучи до реципієнта через почуття, сучасний масмедійний дискурс набуває яскравого емоційного забарвлення. Посилення виразності медіа-текстів виокремлює їх 3-поміж інших, 
надає їм своєрідності та в кінцевому рахунку сприяє підвищенню їхньої перлокутивної ефективності» [7, с. 59].

Використання кліше в мові мас-медіа, з одного боку, має на меті впізнати відомі текстові фрагменти, а 3 іншого, - покликане «нав'язувати певну інтерпретацію, конструювати необхідні пресупозиції чи надавати (з погляду адресата очікувану й бажану) неоднозначність. ...Уся експресія, економна форма подання певної інформації в зіткненні з індивідуальним контекстом - неповторним, але повторюваним відчуттям негативно-оцінного значення, приводять до породження нових смислів і контекстів» (А. Пстига). Наприклад, поширеними в медіакомунікації $є$ мовні одиниці на зразок Справи судові («События дня», канал «Україна», 23.02.2015); Гучні справи. Урядові рішення («Вікна», канал СТБ, 23.03.2015); Музична пауза («События дня», канал «Украина», 04.06.2014); політичні проблеми («Урядовий кур'єр», 16-19.03.13); національний складник (газ. «Урядовий кур'єр», 16-19.03.13); взаємна неузгодженість пріоритетів («Українська правда», http://pravda.com.ua, 19.11.2013); гуманний акт («ШО», 25.03.13).

Внутрішні суспільні зміни в Україні і зовнішньополітичні події детермінували продукування мовних одиниць за наведеною типовою формулою, що стало наслідком актуалізації в публіцистичних текстах спеціального прийому - руйнування кліше (Н. Кваша). У сучасній медіакомунікації це $\epsilon$ виразним стилістичним явищем, оскільки засвідчено низку мовних фактів, які кваліфікуємо як семіотичні репродукти. Так, у медіатекстах і блогосфері інтернет-комунікації функціонують висловлення, побудовані за однаковою моделлю: Україна не Росія (А. Куликов. «Кліше про Україну», http://blog.comments.ua/?p=152; 16.12.2010); Маріуполь - че Украӥна («Новини», 5-й канал, 24.01.2015); Маріуполь не Донецьк («Новини», 5-й канал, 24.01.2015); Крим - не Украӥна (www.hromadsketv; 01.03.2014). Крім того, це спостерігаємо також і в російськомовних інформаційних ресурсах: Правый Сектор - это не вся Украина (my.mail.ru/mail/hmelnickaya.oblast; 30.08.2014); Крым - это не Россия (twitter.com/glavcomua/articles/21300). Прагматика таких лінгвем досягається за допомогою цілеспрямованого маніпулятивного впливу на масового адресата, спрямованій сугестії вербальних і невербальних (психологічних, інтелектуальних та інших) засобів, які реалізують 
прагматичну настанову автора публікації. Використання метамодельного маркера - «пресупозитивного забарвлення номенів та сигнатур» [9, с. 239] - пояснює викривлення інваріанту змісту кліше, який сприймається апріорі, а «заповнення одного речення різними типами пресупозицій спричиняє їх виняткову силу» (Р. Бендлер, Д. Гриндер).

Маніпуляція масовою свідомістю за допомогою мовних кліше відбувається на основі використання прийому «наклеювання ярликів» певним суспільним артефактам і подіям [5; 6, с. 88]. Прагматичне навантаження кліше, які мають національне маркування, дає змогу долати етнічні межі, уведення їх у видання нав'язує аксіологічну проекцію: Українська криза (криза в Україні; Ukraine Crisis); Кримська криза (Крымский кризис; Crimea Crisis). Серед стереотипних одиниць у мові сучасних вітчизняних медіа варто виокремити такі, що мають виразний етнічний компонент як репрезентант опозиції «свій - чужий», яка охоплює етнічний i соціокультурний простір та постає одним із головних полярних концентрів масового світосприйняття актуальної інформації, що детермінує парадигматичні ряди: синонімічні (конфлікт на Донбасі /сході Украӥни/; українські військові /силовики, кіборги/; російські (проросійські) сепаратисти /найманці, бойовики/; силовий сченарій; югославський / грузинський / єгипетський сценарій; антонімічні: «Російська (українська) весна» / «Українське літо»; анексований /наш Крим; звільнена /окупована територія; гіперо-гіпонімічні: сепаратистські угрупування /ополченці Донбасу/ «герої Новоросї̈».

Активно в українських засобах масової інформації застосовують таку складову маніпулятивного впливу, як використання кількісних показників у вербальному оформленні, що може супроводжуватися кількісною семантикою (із цифровими позначеннями), графічними зображеннями: Bci dimu світу плачуть однісю мовою (гасло UNICEF благодійного фонду «З надією»); Перший раунд («События дня», канал «Україна», 05.06.2014) - репортаж про перший день перебування В. Кличка на посаді мера Києва та представництво його політсили «Удар» у Київраді; Перше засідання («Вікна», канал СТБ, 06.06.2014). Кількісні показники перш за все апелюють до раціональної сфери адресата, проте в більшості випадків застосовуються саме для впливу на емоційну сферу (що пов'язано 3 
нагнітанням страху), можуть створювати своєрідне нівелювання великою кількістю цифр чи - найчастіше - неозначеністю числа. Тут варто згадати і семіотичні реконструкти в заголовках медіатекстів гасла Помаранчевої революції Разом нас багато, нас не подолати!: Разом їх багато («Вікна», канал СТБ, 27.02.2009; 22.02.2013) тощо.

Чіткість, стислість, запам'ятовуваність окреслили функціональність подібних одиниць, яким притаманний прецедентний характер i які відображають політичне або інтелектуальне кредо суспільства, що прагне до оновлення, не лише в політичному дискурсі, а й мас-медійному, коли кліше не зазнають трансформації: Перші дізнаються периими (ТСН, канал «1+1», 16.09.2008); Один вдома («События дня», канал «Украина», 04.11.2013); Сxid $i$ Захід разом («Вікна. Новини. Спецвипуск», канал СТБ, 26.02.2014; ТСН, канал «1+1», 01.04.2014). У зв'язку з цим Н. В. Кондратенко зазначає: «Цю тенденцію можна визначити як афористичність, що спричинена специфікою функціонування слоганів: від вираження сталої ідеї політичної кампанії до скандування на мітингах. Слогани настільки чітко впливали на свідомість, що добре запам'ятовувалися, переказувалися, переосмислювалися і навіть ставали об’єктом для чорного PR. Основною ознакою такого закріплення в масовій свідомості $\epsilon$ перекручування гасла» [9, с. 272]. Наприклад, гасла радянської доби Битва за Батьківщину (врожай); Все для фронту, все для перемоги! набули переосмислення, що позначено в сучасній медіакомунікації як Битва за Схід («События дня», канал «Україна», 28.05.2014; «Вікна», канал СТБ, 21.02.2015); Битва за прапор («Вікна. Новини. Спецвипуск», канал СТБ, 26.02.2014); Битва за правду («Вікна», канал СТБ, 29.04.2015); Очі для фронту («Вікна», канал СТБ, 29.04.2015). Відтак стилістичний прийом руйнування кліше в новітніх медіа спричинив появу нових стереотипних одиниць, які відображають реалї українського сьогодення.

Назвами рубрик інформаційно-аналітичних програм, відеороликів $\epsilon$ мовні одиниці, впливові потенції яких становлять дієслова на позначення ментальної дії та темпоральних меж як метамодельні морфологічні маркери сугестії [9, с. 239], як-от: Живи $i$ плати («События дня», канал «Украина», 03.06.2014); Живи серед вічних цінностей (рекламне кліше, 11-й канал); Живи з новинами (гасло 5-го каналу); Звіримо час (канал СТБ, 22.02.2013). Подібні кліше позначені (C) Н. М. Шарманова, 2015. 
виразною прагматичною настановою, містять прямі, неприховані команди. Це транслює діалогічність та інтерактивність медіакомунікації, адже «вплив у масовій комунікації існує у формі діалогічного спілкування, у якому комунікатор послідовно програє передбачувані дії учасників соціальної взаємодії» [12, с. 55]. Проте діалог як такий відсутній, адже мета таких впливів чітко окреслена. О. Г. Руда розвиває таку позицію О. І. Шейгал і пише: «По суті, маніпуляція $є$ нескінченним монологом, в якому якщо й з'являється 'опонент', то найчастіше він виявляється організованим об' єктом, а не суб'єктом комунікації. Перехід владних відносин у дискурсивну форму означає, що сила виявляє себе в праві говорити і в праві позбавляти цієї можливості інших» [10, с. 53].

В основі багатьох стереотипних одиниць лежить власне питання, наприклад: Хто платить? («Вікна», канал СТБ, 04.04.2014); Що nочому? («События дня», канал «Україна», 11.06.2014); Що ие за люди? («События дня», канал «Україна», 11.06.2014); Де гроші? (ТСН, канал «1+1», 20.02.2015); Чи правий сектор? («Вікна», канал СТБ, 29.04.2015). Подібні лінгвеми кваліфікують як різновид «непрямих гіпнотичних патернів» (М. Еріксон) - «розмовні постулати, що репрезентують такі формулювання запитань (прохань), які вже містять потрібну реакцію без прямого прохання щодо неї» [9, с. 240]. Н. В. Кутуза зазначає з цього приводу, що специфіка техніки наказу, прихованого в питанні, полягає в заміщенні такою структурою власне прохання щось зробити: «Реакція реципієнта - виконати дії, а не відповідь» [9, с. 221]. Більш виразний медіавплив відстежується в питальних конструкціях, утворених із використанням прийому редукції: Нові санкціï? («Час новин», 5-й канал, 11.04.2014); Новий cвim? («События дня», канал «Україна», 04.06.2014). Семантична неоднозначність, яка «спричиняє необхідність суб'єктивного заповнення сенсових лакун об'єктивного змісту» $[9$, с. 240], притаманна одиницям Як иче було («Час новин», 5-й канал, 12.01.2014); Не дуже рада («События дня», канал «Україна», 02.06.2014); До бою готові («События дня», канал «Україна», 04.06.2014) тощо.

Отже, дослідження мовних засобів маніпулятивного впливу дає змогу зрозуміти природу новітнього мас-медійного дискурсу, маніпуляції в якому здійснюються за допомогою актуалізаторів мовного (семантичного) маніпулювання - імплікатур, багатозначності, 
емотивної лексики, детермінологізації, переосмислення гасел тощо. Мовні кліше виступають в ролі конструктів медійного спілкування, оформлюючи різні ситуації, визнані узвичаєними в суспільстві правилами й нормами. Дослідження прагматики кліше в масмедійному дискурсі як одного 3 механізмів мовної взаємодії в соціальному середовищі, установлення закономірностей мовного впливу інформації розкривають спроби масових маніпуляцій над суспільною свідомістю.

\section{Література}

1. Безугла Л. Р. Лінгвопрагматика дискримінації у публіцистичному дискурсі : [монографія] / Л. Р. Безугла, І. О. Романченко. - Х. : ФОП Лисенко І. Б., 2013. - 182 с.

2. Бибик С. Колоквіалізація мови преси : нова норма чи саботаж культури спілкування / С. Бибик // Культура слова. - Вип. 79. - К. : Вид. дім Дмитра Бураго, 2013. - C. 133-135.

3. Срмоленко С. Засоби масової комунікації і мовна свідомість сучасного українця / С. Срмоленко // Культура слова. - Вип. 79. - К. : Вид. дім Дмитра Бураго, 2013. C. $123-125$.

4. Завгородня Л. В. Стереотипи породження та сприймання журналістського твору (на матеріалі газетних текстів) : автореф. дис. ... канд. філол. наук / Л. В. Завгородня. K., 2003. - 19 c.

5. Иссерс О. С. Речевое воздействие в аспекте когнитивных категорий [Электронный ресурс] / О. С. Иссерс // Вестник Омского университета. - 1999. - Вып. 1. - Режим доступа : omsu.omskred.ru/vestnik/articles/yl

6. Копнина Г. А. Речевое манипулирование : [учебное пособие] / Г. А. Копнина. М. : Флинта : Наука, 2007. - С. 88.

7. Кудрявцева Л. О. Сучасні аспекти дослідження мас-медійного дискурсу : експресія - вплив - маніпуляція / Л. О. Кудрявцева, Л. П. Дяченко, О. М. Дорофєєва та ін. // Мовознавство. - 2006. - № 1. - С. 58-66.

8. Подшивайлова Г. М. Мовні засоби маніпулятивного впливу в політичному дискурсі (на матеріалі друкованих російськомовних ЗМІ України) : автореф. дис. ... канд. філол. наук / Г. М. Подшивайлова. - К., 2009. - 18 с.

9. Реклама та PR у масовоінформаційному просторі : [монографія] / Т. Ю. Ковалевська, Н. В. Кондратенко, Н. В. Кутуза та ін. ; за заг. ред. О. В. Александрова. - Одеса : Астропринт, 2009. - 400 с.

10. Руда О. Г. Мовне питання як об'єкт маніпулятивних стратегій у сучасному українському політичному дискурсі : [монографія] / О. Г. Руда. - К., 2012. - 232 с.

11. Шмелев Д. Н. Русский язык в его функциональных разновидностях (к постановке проблемы) / Д. Н. Шмелев. - М., 1977. - С. 64.

12. Язык и массовая коммуникация : Социолингвистическое исследование [монография] / Отв. ред. Э. Г. Туманян. - М. : Наука, 1984. - 278 с. 